\title{
Limitations in the Statistical Analysis of Normalised Cigarette Smoke Analyte Yield per Milligram of Nicotine Yield *
}

\author{
by \\ Xavier Cahours ${ }^{1}$, Thomas Verron ${ }^{1}$, Stephen W. Purkis ${ }^{2}$, and Stéphane Colard ${ }^{2}$ \\ ${ }^{1}$ SEITA, Imperial Tobacco Group, 48 rue Danton, 45404 Fleury-les-Aubrais, France \\ ${ }^{2}$ Imperial Tobacco Limited, Winterstoke, Bristol BS99 7UJ, UK
}

\section{SUMMARY}

Yields of selected mainstream smoke analytes expressed per milligram of nicotine yield (nicotine ratio) and ceilings on these ratios have been proposed by WHO as part of future cigarette product regulation. This paper describes the different approaches required for precision assessment, depending on whether yields or nicotine ratios are being studied. The widely used approach of assessment of yield precision is to perform a collaborative study using a standardised method. However, for assessment of ratio precision the measurement of smoke analyte and smoke nicotine yields are often not carried out on the same set of cigarettes (unpaired) due to analytical constraints and therefore the statistical approach described in ISO 5725 is inappropriate due to the various replicate combinations. In this paper, the precision of ratios was computed with unpaired measurements for NNN and nicotine yield data for the CM6 monitor test piece and the Kentucky Reference 1R5F cigarette carried out during a collaborative study in 2011 (1). A sampling technique, based on the draw of the most representative ratios, has been used to evaluate the range of both estimated repeatability and reproducibility under the ISO smoking regime that might be expected when comparing data between different laboratories. This statistical evaluation highlighted that a robust estimate of repeatability and reproducibility could not be determined for ratios obtained with unpaired measurements, using the method defined by ISO5725-2. [Beitr. Tabakforsch. Int. 25 (2013) 617-626]

\section{ZUSAMMENFASSUNG}

Als Teil zukünftiger Produktregulierung für Zigaretten wurde von der WHO vorgeschlagen, den Gehalt von ausgewählten Hauptstromrauchanalyten auf den Nikotingehalt zu beziehen (pro mg Nikotin) und Höchstgrenzen für dieses Verhältnis aufzustellen. Diese Arbeit beschreibt die verschiedenen für die Präzisionsbewertung benötigten Ansätze, je nachdem, ob die Ausbeute oder das Nikotinverhältnis der Ausbeute untersucht werden soll. Ein weit verbreiteter Ansatz zur Bewertung der Ausbeutepräzision besteht in der Durchführung eines Ringversuchs mit einer standardisierten Untersuchungsmethode. Zur Bewertung der Verhältnispräzision erfolgt die Messung der Rauchanalyten und der Nikotinausbeuten im Rauch aufgrund von analytischen Einschränkungen häufig jedoch nicht am selben Zigarettensatz (ungepaart). Daher ist der in ISO 5725 beschriebene statistische Ansatz wegen der Vielzahl möglicher Kombinationen ungeeignet. Für diese Arbeit wurde die Präzision der Verhältniszahlen in einem Ringversuch anhand von ungepaarten Messungen von NNN und Daten zur Nikotinausbeute für die CM6 Referenzzigarette und die Referenzzigarette Kentucky 1R5F errechnet 2011 (1). Es wurde ein Stichprobenverfahren verwendet, das auf der Ziehung der repräsentativsten Verhältnisse beruht, um die Spannbreite der geschätzten Wiederholbarkeit und Reproduzierbarkeit zu ermitteln, die bei Anwendung der nach der ISO-Norm geltenden Verfahren zur Messung des Tabakkonsums aufgrund des Vergleichs von Daten aus verschiedenen Laboren zu erwarten ist. Die statistische Auswertung ergab, dass eine robuste Schätzung der Wiederholbarkeit und Reproduzierbarkeit nicht für 
Verhältniszahlen erzielt werden kann, die auf der Grundlage von ungepaarten Messungen unter Anwendung der in der ISO5725-2 definierten Methode ermittelt wurden. [Beitr. Tabakforsch. Int. 25 (2013) 617-626]

\section{RESUME}

Le groupe d'étude de l'OMS sur la réglementation des produits du tabac (TobReg) a proposé de règlementer les rendements de certains composés de la fumée de cigarette sur la base d'une normalisation par la nicotine. Cependant, avant la mise en place d'une telle règlementation, il est nécessaire d'évaluer la précision des méthodes analytiques utilisées pour analyser la nicotine et les composés de la fumée. L'approche la plus largement utilisée pour l'évaluation de cette précision est la mise en place d'un essai collaboratif permettant l'estimation de la répétabilité et la reproductibilité des méthodes. Toutefois, lorsque, en raison de contraintes analytiques, des méthodes non-appariées sont utilisées pour analyser la nicotine et les composés de la fumée, la détermination de la précision devient problématique en raison de la non unicité de la construction des ratios entre les répétitions du composé de la fumée et de la nicotine. Cette publication montre l'impact de la combinaison des différentes répétitions sur la détermination de la répétabilité et la reproductibilité en utilisant l'approche statistique proposée dans la norme ISO5725. Une technique d'échantillonnage, basée sur le tirage au sort des ratios les plus représentatives, a été utilisée pour évaluer l'incertitude des calculs de répétabilité et reproductibilité en utilisant les mesures appariées de NNN et Nicotine obtenues avec la cigarette CORESTA moniteur CM6 et la Kentucky Reference 1R5F analysées lors de l'étude collaborative CORESTA 2011 (CORESTA, 2012). L'évaluation statistique montre qu'une estimation précise de la répétabilité et la reproductibilité ne peut pas être effectué par la méthode définit par l'ISO5725-2 pour des ratios obtenus avec des résultats non-appariés. [Beitr. Tabakforsch. Int. 25 (2013) 617-626]

\section{INTRODUCTION}

The most common measurements used to categorise cigarette smoke are "tar", nicotine and carbon monoxide (TNCO) yields per cigarette collecting smoke using the International Standards Organization (2) machine smoking regime. TNCO yields are measured on the collected smoke using prescribed ISO testing methods (3-6) which are intended to provide a means of ranking cigarettes in terms of TNCO yields under fixed measuring conditions. The smoking regime and the associated testing methods are robust, tried and tested in providing yields that can be reproduced consistently in laboratories around the world. Many regulatory authorities, including the European Union Directive (7), apply TNCO yield ceilings to the regulation of cigarette smoke mainstream yields and for several decades public health bodies and regulatory authorities viewed the reduction of ISO "tar" yields as a means of reducing adverse effects of cigarette smoking.
However, machine smoking cigarette yields were never intended to reflect individual human smoking yield uptake but rather to consistently rank product yields generated by machine smoking (8). The differences between the standardized machine smoking puff parameters and human puffing topography have been widely reported (9-11). More recently, doubts have been expressed by the WHO about the public health benefits of cigarettes with reduced machine smoking "tar" yields derived under the ISO smoking regime (12). An alternative to this decrease in "tar" yield has been proposed on different occasions, requiring the reduction of "tar" and other smoke analytes relative to nicotine $(13,14)$. The hypothesis put forward was based on the fact that smokers tend to compensate (15) together with the simplistic assumption that compensation is driven by the smokers' wish to regulate their nicotine intake to a constant value (14). If this assumption were true then WHO proposes that it would be favourable to reduce the smoke analyte yield for a given nicotine yield over time. However, it is clear that nicotine only partly contributes to smoke compensation and other factors are also important (16-18). So, for instance, rather than setting a limit on the absolute yield of a smoke analyte, such as $\mathrm{N}^{\prime}$-nitrosonornicotine (NNN), WHO currently proposes to regulate cigarette products based on the limits for the NNN yield per mg of smoke nicotine. To establish tolerances based on nicotine ratio, it is essential to know its precision and for that the widely used method is to perform a collaborative study in order to determine the yield repeatability (r) and reproducibility (R). However, in the case of ratio expression, it is important to distinguish the case in which a same sample is analysed by two analytical methods (paired measurements), and the case in which every analysis is done on a different sample (unpaired measurements). Additional specific sources of variability, such as sampling or smoking runs, that can affect independently each measurement (denominator and numerator) need to be considered when calculated the ratio of two unpaired measurements. In the case of the chosen collaborative study, laboratories provided five replicates for NNN and five replicates for nicotine independent of each other. In other words, analyses were carried out on different Cambridge filter pads (five for nicotine and five for smoke $\mathrm{NNN}$ ), that increased the effect of confounding factors (sampling, smoking runs, extraction and analysis of analytes). Consequently, the computation of ratio (possible combinations of NNN and nicotine replicates) had an impact on the estimation of precision ( $\mathrm{r}$ and $\mathrm{R}$ ). This paper evaluated this impact using data on NNN and nicotine yields of CORESTA (Cooperation Centre for Scientific Research Relative to Tobacco) 6 monitor test pieces and Kentucky 1R5F reference cigarettes obtained during a collaborative study in 2011 managed by the Special Analytes Sub Group of the Cooperation Centre for Scientific Research Relative to Tobacco (1).

\section{EXPERIMENTAL}

\section{Data from CORESTA special analytes task force}

These data are taken from a CORESTA collaborative study, involving 20 laboratories, undertaken to determine 
the intra- and inter-smoking machine/laboratory variability of five mainstream smoke yields of TSNAs, including $\mathrm{NNN}$, from different products. Data obtained under the ISO smoking regime are described in this study. A detailed description of the determination of TSNAs in cigarette mainstream smoke for the 2011 collaborative study is given in the recommended method (1). Cigarette mainstream smoke was collected on a Cambridge filter pad, an internal standard solution was added and after extraction, an aliquot was separated and quantitatively analysed by Liquid Chromatography and Tandem Mass Spectrometry
(LC-MS/MS). For the CORESTA collaborative study, five replicates of each of ten products were smoked in different runs but not necessarily on different days involving five cigarettes per replicate. TNCO yields were also determined on the same ten products according to the ISO3308 (2) standard methodology. Mean NNN and nicotine yields and repeatability and reproducibility data were obtained after outlier removal according to ISO5725-2 (19). For the purposes of this paper, only data for CM6 monitor test pieces and $1 \mathrm{R} 5 \mathrm{~F}$ reference cigarettes, were used illustratively in the analyses.

Table 1. NNN and nicotine yield data from the collaborative study

\begin{tabular}{|c|c|c|c|c|c|c|c|c|c|}
\hline \multirow{2}{*}{$\begin{array}{l}\text { Lab } \\
\text { code }\end{array}$} & \multicolumn{2}{|c|}{ CM6 } & \multicolumn{2}{|c|}{ 1R5F } & \multirow{2}{*}{$\begin{array}{l}\text { Lab } \\
\text { code }\end{array}$} & \multicolumn{2}{|c|}{ CM6 } & \multicolumn{2}{|c|}{ 1R5F } \\
\hline & $\begin{array}{c}\text { NNN } \\
\text { (ng/cig) }\end{array}$ & $\begin{array}{l}\text { Nicotine } \\
\text { (mg/cig) }\end{array}$ & $\begin{array}{c}\text { NNN } \\
\text { (ng/cig) }\end{array}$ & $\begin{array}{l}\text { Nicotine } \\
\text { (mg/cig) }\end{array}$ & & $\begin{array}{c}\text { NNN } \\
\text { (ng/cig) }\end{array}$ & $\begin{array}{l}\text { Nicotine } \\
\text { (mg/cig) }\end{array}$ & $\begin{array}{c}\text { NNN } \\
\text { (ng/cig) }\end{array}$ & $\begin{array}{l}\text { Nicotine } \\
\text { (mg/cig) }\end{array}$ \\
\hline 1 & $\begin{array}{l}18.30 \\
17.50 \\
18.40 \\
17.00 \\
18.60\end{array}$ & $\begin{array}{l}1.36 \\
1.36 \\
1.50 \\
1.42 \\
1.38\end{array}$ & $\begin{array}{l}48.90 \\
51.60 \\
50.20 \\
52.60 \\
54.20\end{array}$ & $\begin{array}{l}0.17 \\
0.18 \\
0.17 \\
0.18 \\
0.17\end{array}$ & 11 & $\begin{array}{l}19.60 \\
20.70 \\
20.00 \\
20.10 \\
18.60\end{array}$ & $\begin{array}{l}1.38 \\
1.36 \\
1.36 \\
1.33 \\
1.35\end{array}$ & $\begin{array}{l}41.30 \\
46.90 \\
44.90 \\
50.40 \\
44.40\end{array}$ & $\begin{array}{l}0.21 \\
0.21 \\
0.20 \\
0.19 \\
0.19\end{array}$ \\
\hline 2 & $\begin{array}{l}20.70 \\
19.60 \\
20.80 \\
19.50 \\
21.00\end{array}$ & $\begin{array}{l}1.67 \\
1.46 \\
1.45 \\
1.45 \\
1.48\end{array}$ & $\begin{array}{l}46.00 \\
40.80 \\
50.80 \\
49.20 \\
40.80\end{array}$ & $\begin{array}{l}0.16 \\
0.17 \\
0.17 \\
0.15 \\
0.14\end{array}$ & 12 & $\begin{array}{l}24.60 \\
23.28 \\
20.96 \\
24.68 \\
25.68\end{array}$ & $\begin{array}{l}1.39 \\
1.41 \\
1.40 \\
1.42 \\
1.40\end{array}$ & $\begin{array}{l}35.48 \\
35.00 \\
34.88 \\
37.48 \\
36.68\end{array}$ & $\begin{array}{l}0.15 \\
0.16 \\
0.16 \\
0.16 \\
0.15\end{array}$ \\
\hline 3 & $\begin{array}{l}17.50 \\
18.57 \\
18.81 \\
19.72 \\
16.27\end{array}$ & $\begin{array}{l}1.32 \\
1.32 \\
1.35 \\
1.37 \\
1.34\end{array}$ & $\begin{array}{l}40.12 \\
36.61 \\
46.66 \\
42.41 \\
41.45\end{array}$ & $\begin{array}{l}0.16 \\
0.17 \\
0.18 \\
0.16 \\
0.15\end{array}$ & 13 & $\begin{array}{l}37.78 \\
34.76 \\
39.86 \\
37.77 \\
38.62\end{array}$ & $\begin{array}{l}1.32 \\
1.32 \\
1.34 \\
1.33 \\
1.38\end{array}$ & $\begin{array}{l}44.93 \\
50.74 \\
46.05 \\
47.70 \\
44.58\end{array}$ & $\begin{array}{l}0.17 \\
0.18 \\
0.19 \\
0.18 \\
0.18\end{array}$ \\
\hline 4 & $\begin{array}{l}24.44 \\
21.16 \\
20.60 \\
21.48 \\
20.56\end{array}$ & $\begin{array}{l}1.33 \\
1.38 \\
1.42 \\
1.32 \\
1.42\end{array}$ & $\begin{array}{l}53.20 \\
56.80 \\
57.60 \\
54.80 \\
56.00\end{array}$ & $\begin{array}{c}0.16 \\
0.15 \\
0.17 \\
0.15 \\
\text { NA }\end{array}$ & 14 & $\begin{array}{l}17.24 \\
15.64 \\
18.27 \\
13.66 \\
17.13\end{array}$ & $\begin{array}{l}1.32 \\
1.41 \\
1.49 \\
1.43 \\
1.47\end{array}$ & $\begin{array}{l}33.12 \\
32.70 \\
36.79 \\
41.70 \\
39.66\end{array}$ & $\begin{array}{l}0.14 \\
0.15 \\
0.16 \\
0.15 \\
0.14\end{array}$ \\
\hline 5 & $\begin{array}{l}23.92 \\
24.33 \\
21.37 \\
22.08 \\
22.91\end{array}$ & $\begin{array}{l}1.34 \\
1.44 \\
1.31 \\
1.33 \\
1.30\end{array}$ & $\begin{array}{l}41.33 \\
39.41 \\
38.59 \\
41.24 \\
38.67\end{array}$ & $\begin{array}{l}0.16 \\
0.16 \\
0.15 \\
0.17 \\
0.14\end{array}$ & 15 & $\begin{array}{l}21.20 \\
24.60 \\
23.30 \\
21.90 \\
20.10\end{array}$ & $\begin{array}{l}1.51 \\
1.49 \\
1.51 \\
1.51 \\
1.52\end{array}$ & $\begin{array}{l}36.40 \\
40.60 \\
44.50 \\
37.40 \\
43.50\end{array}$ & $\begin{array}{l}0.11 \\
0.11 \\
0.11 \\
0.11 \\
0.10\end{array}$ \\
\hline 6 & $\begin{array}{l}21.50 \\
19.20 \\
14.70 \\
19.80 \\
15.10\end{array}$ & $\begin{array}{l}1.41 \\
1.40 \\
1.40 \\
1.39 \\
1.35\end{array}$ & $\begin{array}{l}43.20 \\
46.50 \\
41.00 \\
49.00 \\
41.20\end{array}$ & $\begin{array}{l}0.15 \\
0.16 \\
0.15 \\
0.17 \\
0.15\end{array}$ & 16 & $\begin{array}{l}17.08 \\
19.80 \\
22.17 \\
25.66 \\
19.11\end{array}$ & $\begin{array}{l}1.52 \\
1.44 \\
1.49 \\
1.43 \\
1.46\end{array}$ & $\begin{array}{l}40.91 \\
43.01 \\
53.38 \\
41.98 \\
42.36\end{array}$ & $\begin{array}{l}0.22 \\
0.18 \\
0.20 \\
0.19 \\
0.18\end{array}$ \\
\hline 7 & $\begin{array}{l}21.40 \\
20.75 \\
20.40 \\
20.00 \\
21.15\end{array}$ & $\begin{array}{l}1.34 \\
1.35 \\
1.33 \\
1.34 \\
1.34\end{array}$ & $\begin{array}{l}51.48 \\
53.25 \\
51.75 \\
49.58 \\
51.00\end{array}$ & $\begin{array}{l}0.16 \\
0.15 \\
0.16 \\
0.17 \\
0.16\end{array}$ & 17 & $\begin{array}{l}18.50 \\
17.00 \\
16.70 \\
18.80 \\
17.60\end{array}$ & $\begin{array}{l}1.34 \\
1.43 \\
1.35 \\
1.38 \\
1.37\end{array}$ & $\begin{array}{l}43.10 \\
41.10 \\
38.60 \\
43.30 \\
37.10\end{array}$ & $\begin{array}{l}0.16 \\
0.14 \\
0.18 \\
0.14 \\
0.17\end{array}$ \\
\hline 8 & $\begin{array}{l}18.52 \\
21.96 \\
18.52 \\
20.80 \\
20.04\end{array}$ & $\begin{array}{l}1.39 \\
1.39 \\
1.45 \\
1.43 \\
1.38\end{array}$ & $\begin{array}{l}35.28 \\
36.88 \\
33.72 \\
38.96 \\
36.84\end{array}$ & $\begin{array}{l}0.16 \\
0.16 \\
0.16 \\
0.16 \\
0.15\end{array}$ & 18 & $\begin{array}{l}24.74 \\
26.67 \\
28.57 \\
22.83 \\
26.26\end{array}$ & $\begin{array}{l}1.37 \\
1.36 \\
1.34 \\
1.38 \\
1.35\end{array}$ & $\begin{array}{l}42.06 \\
49.38 \\
49.22 \\
43.98 \\
43.96\end{array}$ & $\begin{array}{l}0.14 \\
0.18 \\
0.16 \\
0.16 \\
0.15\end{array}$ \\
\hline 9 & $\begin{array}{l}22.68 \\
19.76 \\
18.56 \\
15.56 \\
17.80\end{array}$ & $\begin{array}{l}1.29 \\
1.29 \\
1.35 \\
1.30 \\
1.26\end{array}$ & $\begin{array}{l}49.60 \\
43.60 \\
40.40 \\
38.52 \\
40.80\end{array}$ & $\begin{array}{l}0.18 \\
0.13 \\
0.15 \\
0.16 \\
0.16\end{array}$ & 19 & $\begin{array}{l}18.44 \\
20.22 \\
20.85 \\
18.98 \\
17.93\end{array}$ & $\begin{array}{l}1.22 \\
1.44 \\
1.36 \\
1.40 \\
1.36\end{array}$ & $\begin{array}{l}46.55 \\
42.67 \\
48.45 \\
44.86 \\
44.59\end{array}$ & $\begin{array}{l}0.16 \\
0.16 \\
0.17 \\
0.17 \\
0.15\end{array}$ \\
\hline 10 & $\begin{array}{l}23.35 \\
19.73 \\
16.95 \\
18.53 \\
20.47\end{array}$ & $\begin{array}{l}1.25 \\
1.28 \\
1.30 \\
1.33 \\
1.32\end{array}$ & $\begin{array}{l}48.60 \\
45.94 \\
41.75 \\
47.15 \\
47.29\end{array}$ & $\begin{array}{l}0.17 \\
0.16 \\
0.17 \\
0.18 \\
0.17\end{array}$ & 20 & $\begin{array}{l}16.90 \\
18.20 \\
16.20 \\
19.85 \\
20.10\end{array}$ & $\begin{array}{l}1.38 \\
1.41 \\
1.30 \\
1.40 \\
1.34\end{array}$ & $\begin{array}{l}48.60 \\
44.05 \\
46.55 \\
50.50 \\
48.35\end{array}$ & $\begin{array}{l}0.19 \\
0.18 \\
0.17 \\
0.18 \\
0.18\end{array}$ \\
\hline
\end{tabular}


The NNN and nicotine yield data for the CM6 monitor test piece and the Kentucky Reference 1R5F cigarette have been extracted from the CORESTA 2011 collaborative study and are given in Table 1.

\section{Evaluation of $r$ and $R$ with absolute yield data}

In general terms, during a collaborative study that is focused on the determination of one compound (A), the design of the dataset is drawn up from compound yield (A) obtained in several laboratories $(\mathrm{P})$ with replicates $(\mathrm{N})$ (Figure 1).

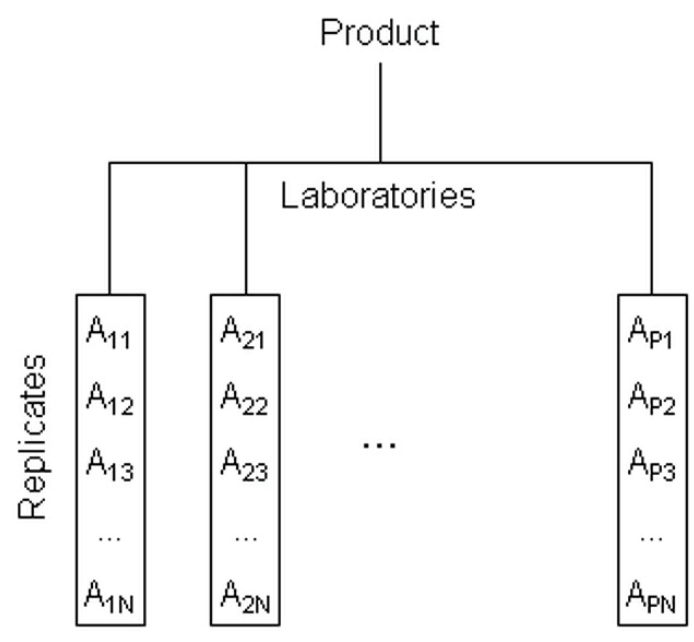

Figure 1. Experimental design for a collaborative study focused on one measured analyte.

(Compound $A$; laboratories $(p)$ from 1 to $P$; replicate $(n)$ from 1 to $N$ $A_{p n}=$ replicate $n$ carried out by the laboratory $p$ for the smoke compound $A$.

The statistical evaluation of data is based on the statistical tests provided by ISO5725-2 (19) and the "harmonized statistical procedure" defined by the International Union of Pure and Applied Chemistry (IUPAC) (20). The overall protocol consists of sequential applications of the Cochran and Grubbs tests until no further outliers are detected or until a drop of no more than $22.2 \%$ in the original number of laboratories would occur. After outlier removal, the repeatability and reproducibility are estimated on the remaining dataset.

The NNN and nicotine mean yields, repeatability and reproducibility data for the both sample have been calculated and are given in Table 2.

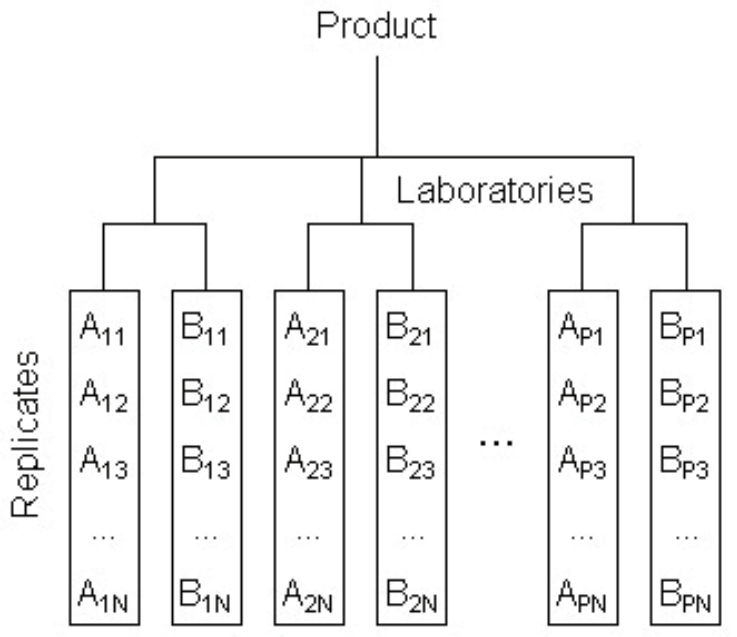

Figure 2. Experimental design for a collaborative study based on the ratio of two compounds.

(Compounds A and B; laboratories (p) from 1 to $P$; replicate $(n)$ from 1 to $\mathrm{N}$ )

$A_{p n}=$ replicate $n$ carried out by the laboratory $p$ for the compound $A$. $\mathrm{B}_{\mathrm{pn}}=$ replicate $\mathrm{n}$ carried out by the laboratory $\mathrm{p}$ for the compound $\mathrm{B}$.

\section{Evaluation of $r$ and $R$ with nicotine ratio data}

During a collaborative study that is focused on the ratio of two cigarette smoke analytes (for example, A and B) the design of the dataset is drawn up from the analyte yields (A and B), obtained in several laboratories $(\mathrm{P})$ with replicates $(\mathrm{N})$ (Figure 2).

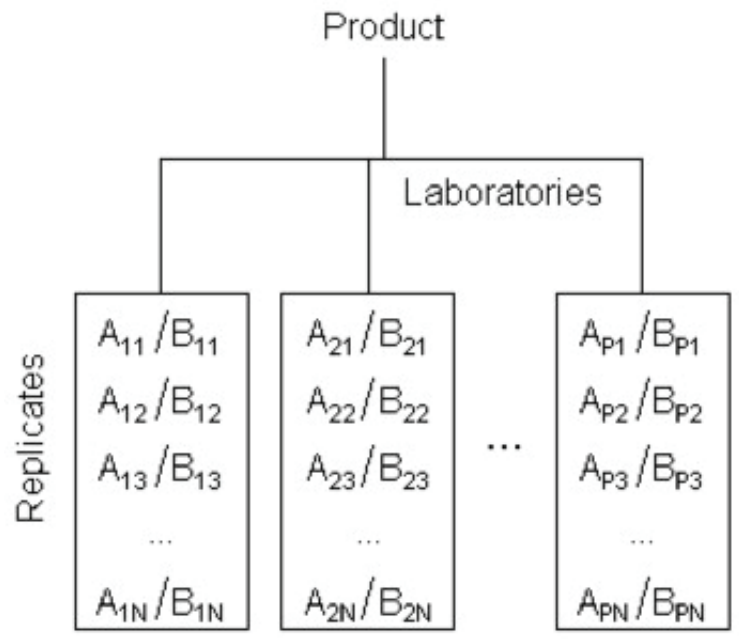

Figure 3. Experimental design for a collaborative study based on the ratio of two compounds with paired measurement. (Compounds A and B; laboratories (p) from 1 to P; replicate (n) from 1 to $\mathrm{N}$ )

$A_{p n}=$ replicate $n$ carried out by the laboratory $p$ for the compound $A$. $\mathrm{B}_{\mathrm{pn}}=$ replicate $\mathrm{n}$ carried out by the laboratory $\mathrm{p}$ for the compound $\mathrm{B}$.

Table 2. Mean yields, repeatability $(r)$ and reproducibility $(R)$ values obtained with NNN and nicotine yield data from the collaborative study.

\begin{tabular}{l|c|c|c|c|c|c}
\hline \multirow{3}{*}{ Sample } & \multicolumn{4}{|c|}{ Nicotine } & \multicolumn{2}{c}{$\mathrm{NNN}$} \\
\cline { 2 - 7 } & $\begin{array}{c}\text { Mean yield } \\
(\mathrm{mg})\end{array}$ & $\begin{array}{c}r(\mathrm{mg}) \\
{[\% \text { of mean] }}\end{array}$ & $\begin{array}{c}\mathrm{R}(\mathrm{mg}) \\
{[\% \text { of mean] }}\end{array}$ & $\begin{array}{c}\text { Mean yield } \\
(\mathrm{ng})\end{array}$ & $\begin{array}{c}\mathrm{r}(\mathrm{ng}) \\
{[\% \text { of mean] }}\end{array}$ & $\begin{array}{c}\mathrm{R}(\mathrm{ng}) \\
{[\% \text { of mean] }}\end{array}$ \\
\hline CM6 & 1.38 & $0.13[9 \%]$ & $0.21[15 \%]$ & 20.0 & $5.1[26 \%]$ & $8.1[41 \%]$ \\
1R5F & 0.16 & $0.03[19 \%]$ & $0.06[37 \%]$ & 44.4 & $8.6[19 \%]$ & $16.7[38 \%]$ \\
\hline
\end{tabular}


This design had either paired or unpaired measurements. Paired measurements are obtained in the case where yields of Analytes A and B are carried out on the same cigarettes and both A and B are collected in the same smoke sample. Such an example is nicotine and "tar" which are collected on the same Cambridge filter pad which is used subsequently for analyzing both analytes. In this case, for each laboratory, the replicate $\mathrm{n}$ for A can be divided by the replicate $\mathrm{n}$ for $\mathrm{B}$ (Figure 3).

In such cases, the experimental design can be drawn up as a collaborative study on absolute yield data. Therefore, if the basic statistical assumptions are valid (e.g. normal distribution of data), ISO5725-2 (19) can be applied for outlier detection and repeatability and reproducibility determination.

Unpaired measurements are obtained when the methods of sample preparation and analytical determination used to measure the two analytes are different and where it is therefore not possible to apply the approach described in Figure 3. Such an example are nicotine and NNN yield measurements which are not carried out on the same cigarettes. For each product, each laboratory will smoke five replicates to determine Analyte A (NNN) and five replicates to determine Analyte B (nicotine) on two different sets of cigarettes. In this case, because there are two different methods for measuring TSNA and nicotine, respec- tively (meaning two datasets of cigarettes, two smoking runs carried out with linear and/or rotary smoking machines, two Cambridge filter pads, two sample preparations and two analytical methods), we must consider two different samples for each analyte.

Consequently, for a given product, Replicate 1 from Laboratory $\mathrm{p}$ for Analyte $\mathrm{A}$ (named $\mathrm{A}_{\mathrm{p} 1}$ ) does not have a direct link with Replicate 1 from Laboratory $\mathrm{p}$ for Analyte $\mathrm{B}$ $\left(\mathrm{B}_{\mathrm{p} 1}\right)$. Therefore there are $\mathrm{N}$ combinations for computing the ratio for $\mathrm{A}_{\mathrm{p} 1}: \mathrm{A}_{\mathrm{p} 1} / \mathrm{B}_{\mathrm{p} 1} ; \mathrm{A}_{\mathrm{p} 1} / \mathrm{B}_{\mathrm{p} 2} ; \ldots ; \mathrm{A}_{\mathrm{p} 1} / \mathrm{B}_{\mathrm{pN}}$. Thus, the calculation of repeatability and reproducibility is strongly influenced by the yield data used to generate the ratio.

As an example, repeatability and reproducibility of NNN yield per milligram of nicotine for the CM6 monitor have been calculated by two different approaches:

- $\quad$ Approach 1: replicate $\mathrm{n}(\mathrm{n}=1, \ldots, 5)$ of $\mathrm{NNN}(\mathrm{A})$ divided by the replicate $\mathrm{n}(\mathrm{n}=1, \ldots, 5)$ of nicotine $(\mathrm{B})$ for each laboratory $\mathrm{p}(\mathrm{p}=1, \ldots, 20) \mathrm{A}_{\mathrm{p} 1} / \mathrm{B}_{\mathrm{p} 1} ; \mathrm{A}_{\mathrm{p} 2} / \mathrm{B}_{\mathrm{p} 2}$; $\mathrm{A}_{\mathrm{p} 3} / \mathrm{B}_{\mathrm{p} 3} ; \mathrm{A}_{\mathrm{p} 4} / \mathrm{B}_{\mathrm{p} 4} ; \mathrm{A}_{\mathrm{p} 5} / \mathrm{B}_{\mathrm{p} 5}$.

- Approach 2: random ratio between the replicates of NNN (A) and the replicates of nicotine (B) for each laboratory.

The results from the two different approaches using the CORESTA collaborative study data are summarised in Table 3.
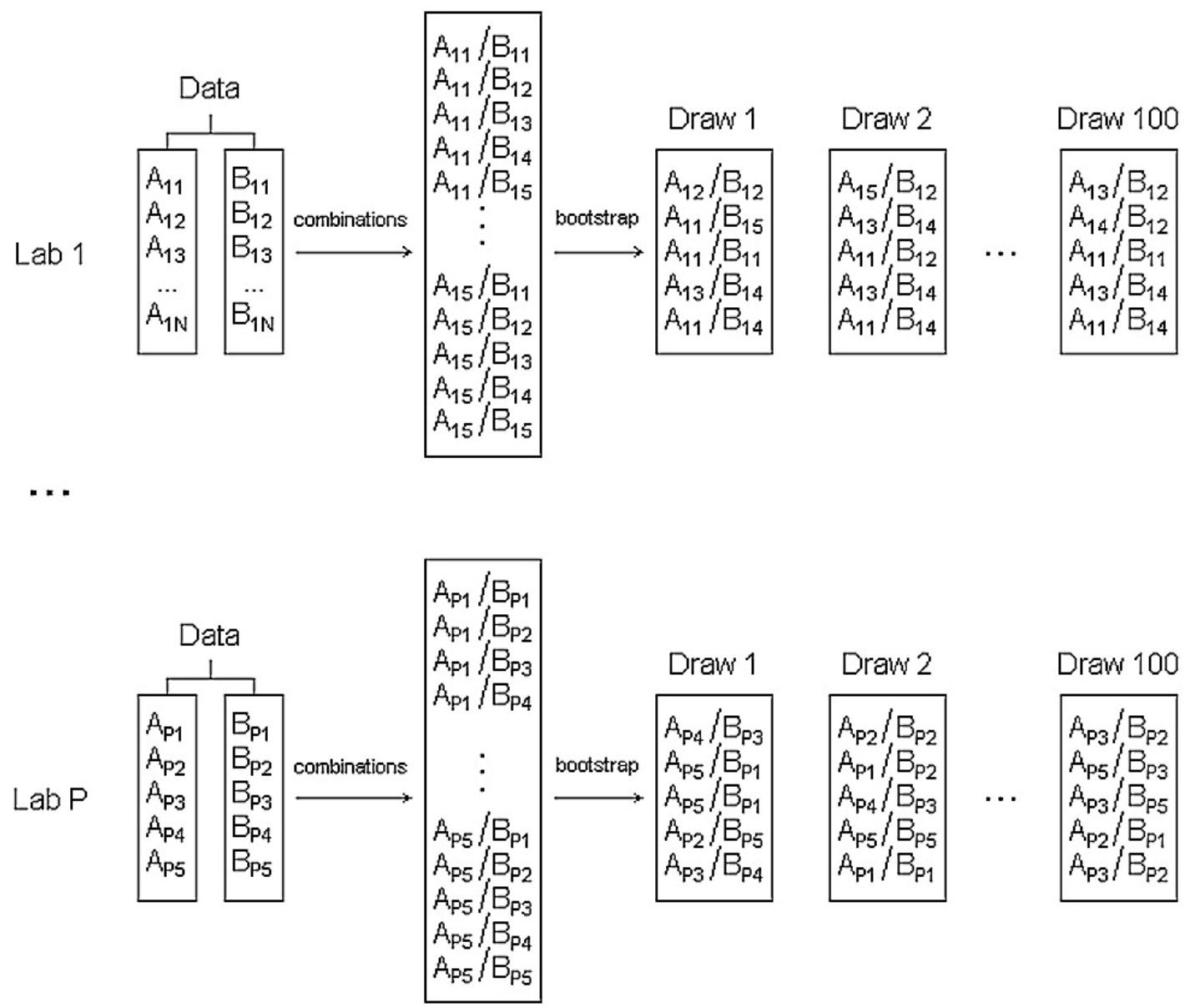

Figure 4. Experimental design for repeatability and reproducibility assessment of the ratio of two compounds with unpaired measurements. 
Table 3. Repeatability ( $r$ ) and reproducibility (R) obtained from two approaches to simulate datasets of NNN/nicotine ratios for the CM6 monitor test piece under the ISO smoking regime.

\begin{tabular}{l|c|c|c|c}
\hline \multirow{2}{*}{ Approach } & \multicolumn{4}{|c}{$\mathrm{NNN}(\mathrm{ng}) /$ nicotine $(\mathrm{mg})$} \\
\cline { 2 - 5 } & Mean & $\mathrm{r}$ & $\mathrm{R}$ & $\begin{array}{c}\mathrm{R} \\
\text { (\% of mean) }\end{array}$ \\
\hline 1 & 14.6 & 4.0 & 6.2 & 42 \\
2 & 14.7 & 3.2 & 5.2 & 35 \\
\hline
\end{tabular}

We can notice that different estimates of the repeatability and reproducibility values for the ratios are obtained for these two approaches. The repeatability and reproducibility varied from 3.2 to 4.0 and from 5.2 to 6.2 , respectively. This example demonstrates that the confounding factors have an impact on the precision assessment.

As the two approaches are not fully representative of the distribution of the repeatability and reproducibility values that can be obtained, a simulation strategy was developed to evaluate the full impact of nicotine ratio computation on precision assessment. This simulation consisted of two main stages (Figure 4).

The first stage was the generation of all the possible ratios by the combinations of replicates of the two analytes. In our study, 25 combinations can be generated (five replicates for $\mathrm{NNN} \times$ five replicates for nicotine). The second stage was to carry out a sampling with replacement called the 'bootstrap' technique (21-22). This is a re-sampling method which consisted of randomly drawing a large number of 're-samples' from the original sample with replacement of the extracted data into the sampled dataset. So, although each re-sample will have the same number of datasets as the original sample, it could have included some of the original data points more than once and some may not be included due to the replacement process. Therefore, each of these re-samples will randomly depart from the original sample (here 25 combinations). This technique favoured the draw of highly represented values and consequently favoured the generation of samples that included the most representative ratios among the set of 25 ratios.

Therefore, the full statistical evaluation consisted of five different steps:

1) outlier detection (Grubbs and Cochran tests) on the raw data sets ( NNN and nicotine).

2) generation of combinations within each laboratory (25 ratios for each laboratory).

3) generation of a ratio data set using the bootstrap technique (five results for each laboratory).

4) outlier detection on the ratio data set.

5) calculation of repeatability ( $r$ ) and reproducibility (R). In order to have a clear view on the impact of the combination of unpaired measurements (ratios) on the estimation of $\mathrm{r}$ and $\mathrm{R}$ values, the steps 3, 4 and 5 have been carried out 100 times. Therefore, at the end of the process, we obtained 100 grand means, 100 repeatability values and 100 reproducibility values (Figure 5).

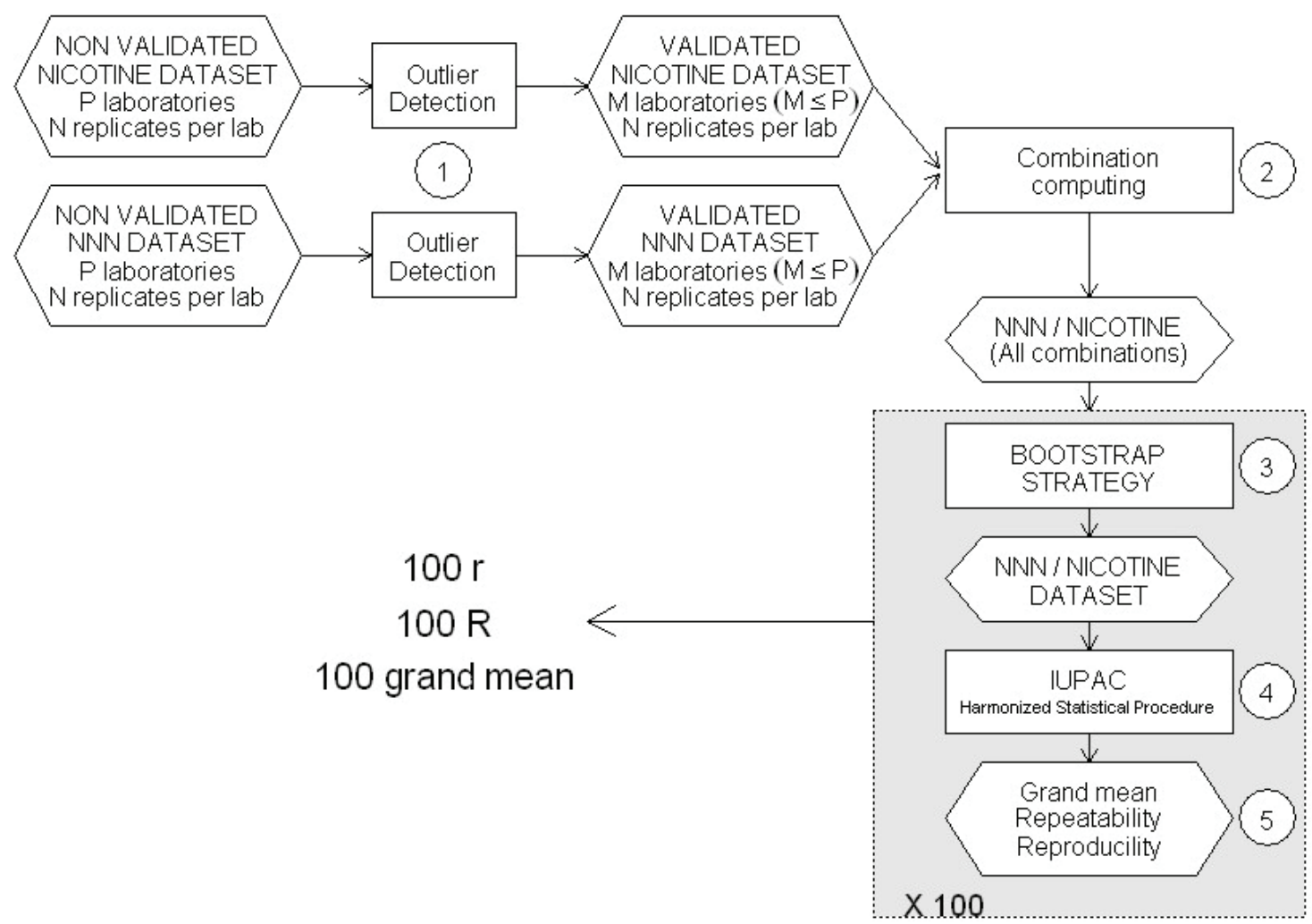

Figure 5. Simulation of $r$ and $R$ using the 'bootstrap' technique. 

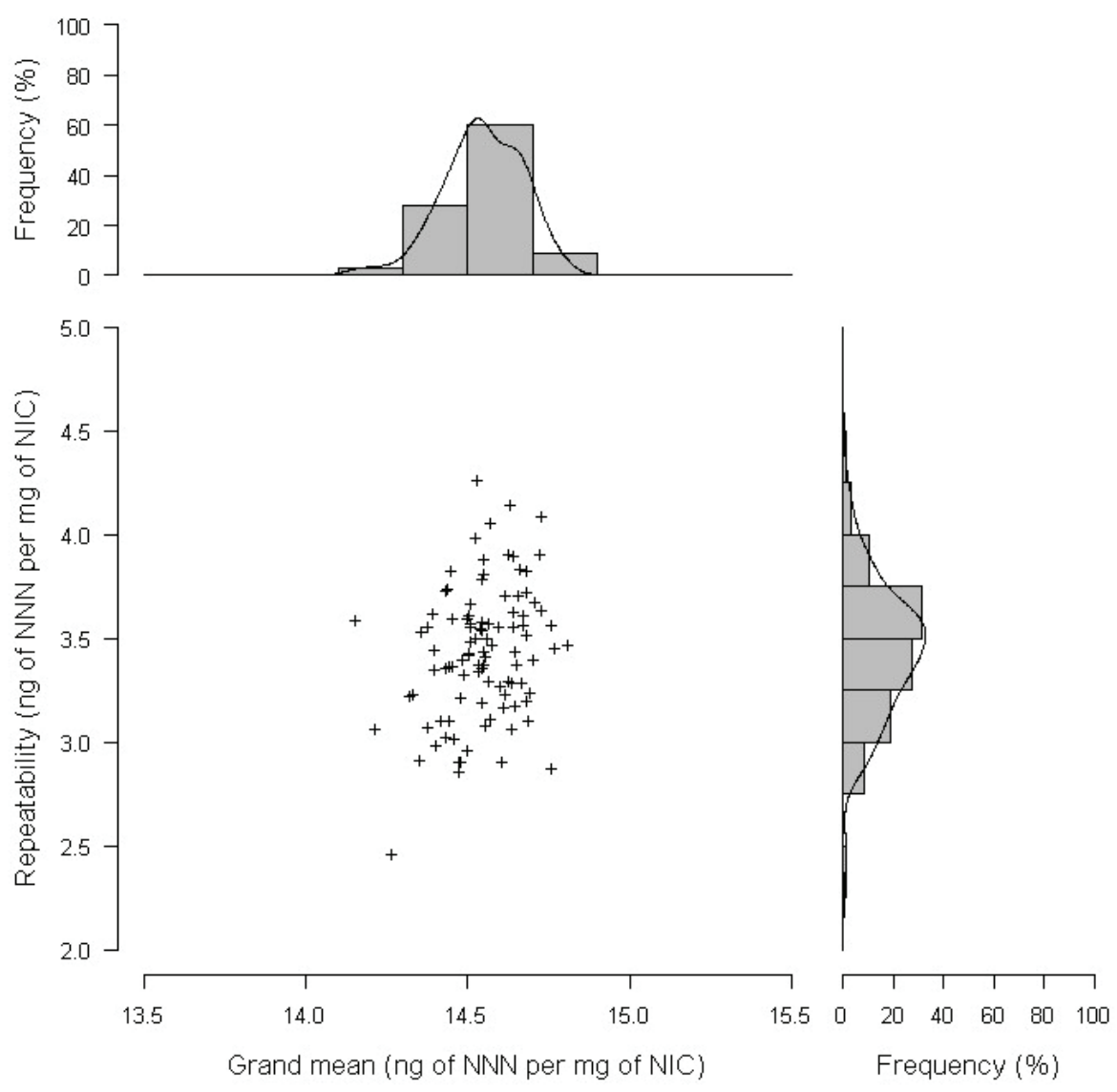

Figure 6a
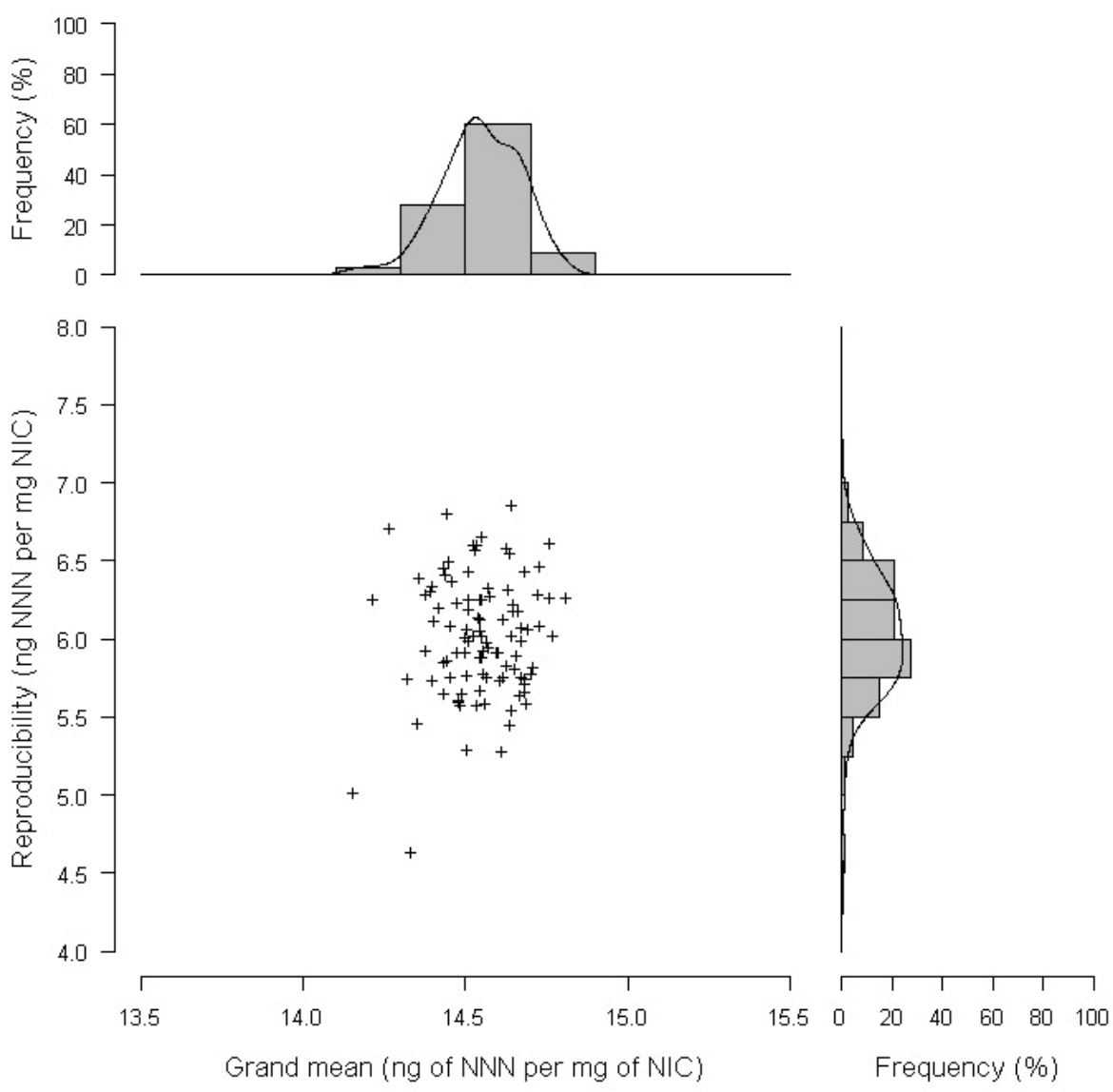

Figure $6 b$

Figure 6. Estimation of repeatability (A) and reproducibility (B) values of NNN/nicotine ratio for the CM6 monitor test piece smoked under the ISO smoking regime using the 'bootstrap' technique. 

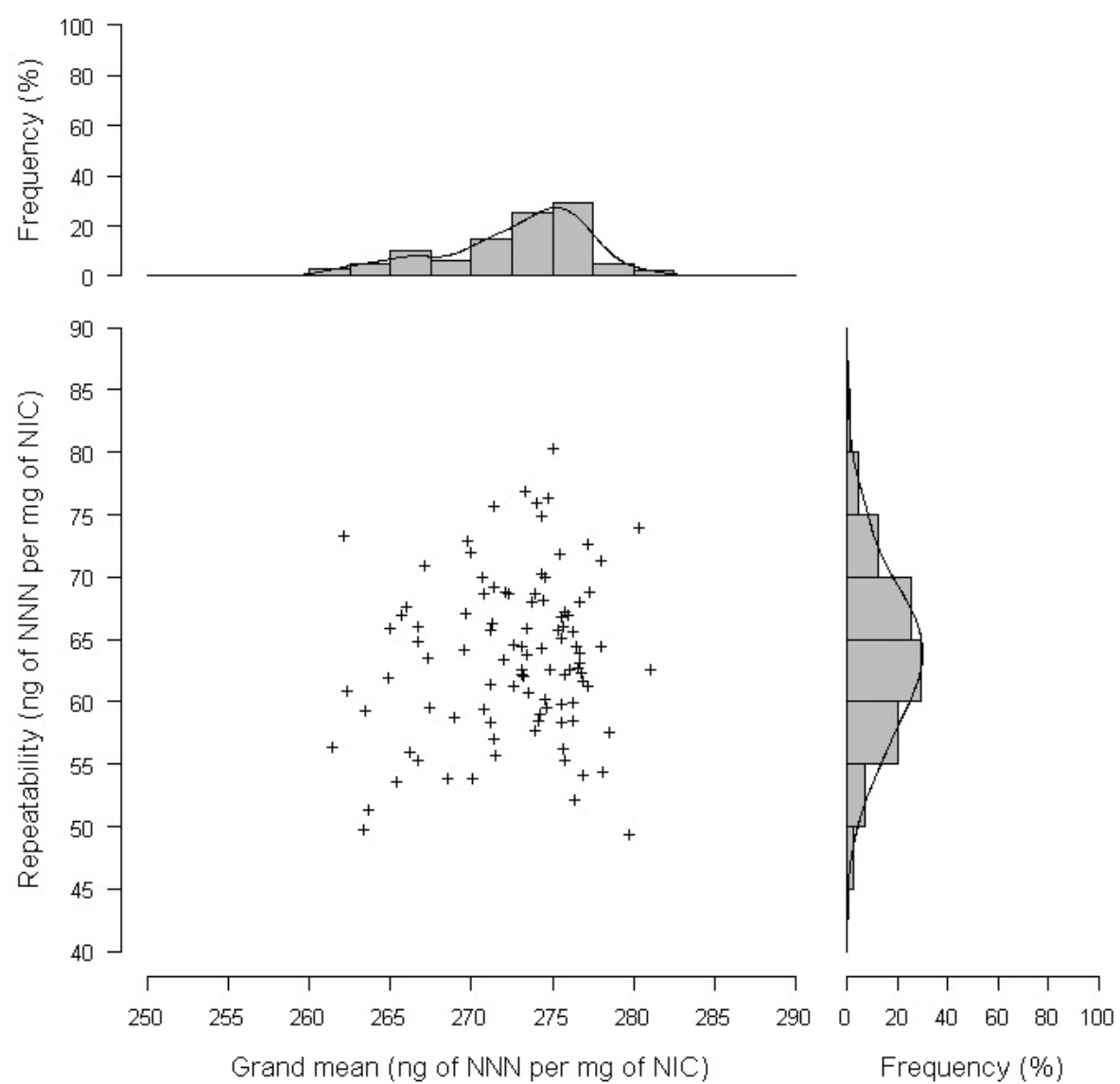

Figure $7 a$
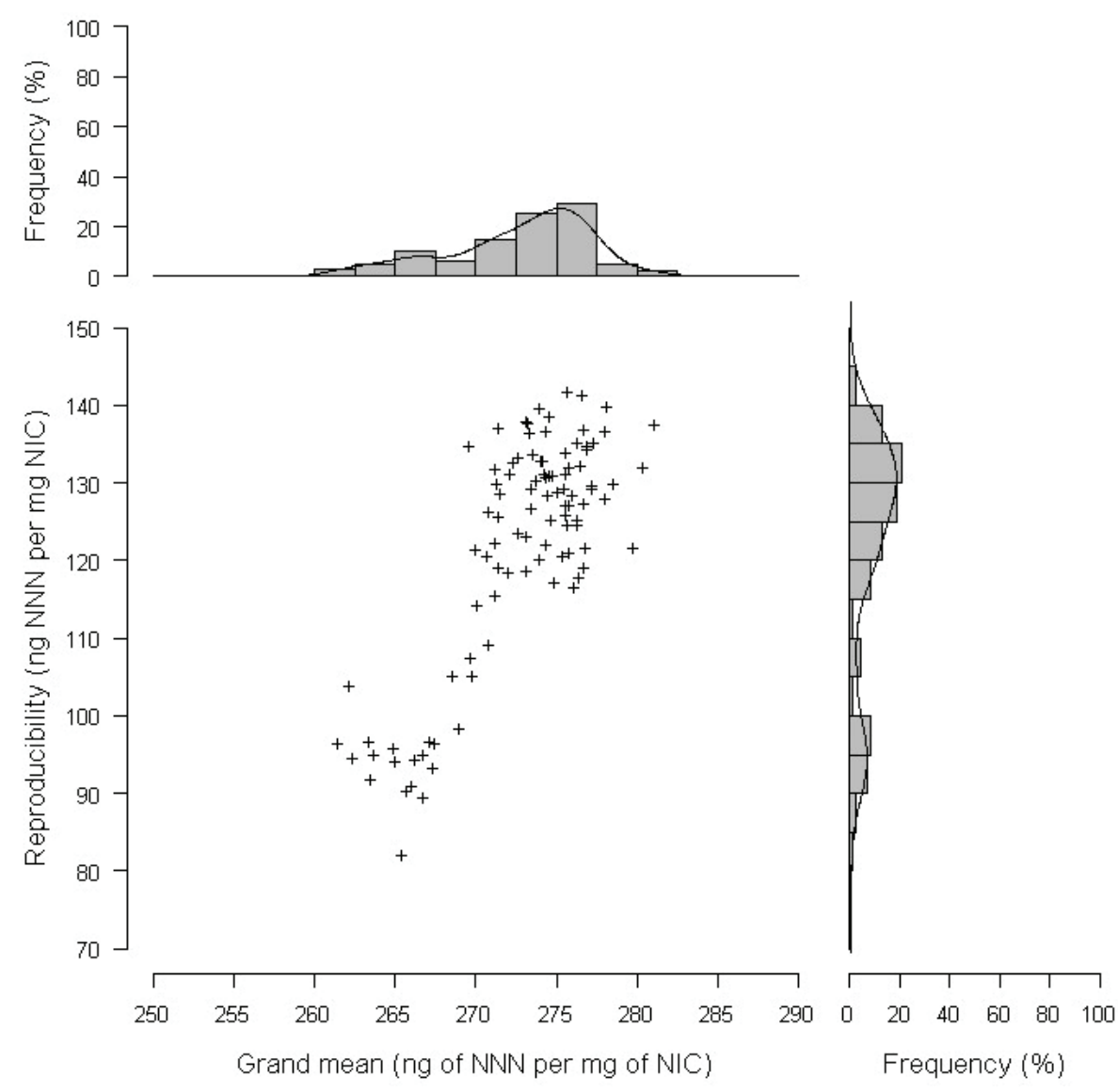

Figure $7 b$

Figure 7. Estimation of repeatability (A) and reproducibility (B) values of NNN/nicotine ratio for the 1 R5F reference cigarette smoked under the ISO smoking regime using the 'bootstrap' technique. 


\section{RESULTS}

Figure 6 and Figure 7 give the basic statistics regarding the $\mathrm{n}=100$ draws obtained by the bootstrap technique for NNN yield per milligram of nicotine for the CM6 and the 1R5F test piece reference from the CORESTA study data. With this simulation, the repeatability and reproducibility estimated for CM6 varied from 2.5 to 4.3 and from 4.6 to 6.9 , respectively (Figure 6).

Concerning $1 \mathrm{R} 5 \mathrm{~F}$, the results show a variation of the repeatability in a range from 49.5 to 80.4 and the reproducibility in a range from 82.3 to 141.2 (Figure 7). In order to determine if the estimated values of repeatability and reproducibility are equivalent or not, a comparison of the two extreme values has been carried out for reproducibility using FISHER's test recommended in ISO 5725 part $6(24)$. These tests showed that the use of the ISO 5725 approach on ratio data with unpaired measurement leads to reproducibility estimations significantly different for both test pieces (CM6 and 1R5F).

\section{DISCUSSION AND CONCLUSIONS}

In order to avoid any misleading conclusions on any measured cigarette yields, the uncertainty of measurements when an analytical method is used in actual practice must be taken into account before any data interpretation. The collaborative study is the most widely used approach for the determination of the yield precision when replicate measurements are made in different laboratories (24).

Many collaborative studies have been carried out to estimate the precision of methods allowing the quantitation of several analytes in cigarette smoke (25-28). These studies were based on measurement of individual smoke analyte yields in many laboratories. In these cases the calculation of $\mathrm{r}$ and $\mathrm{R}$ was carried out according to the method described in ISO 5725-2 (19).

The bootstrap simulation used in this paper clearly shows the impact of the combination of unpaired measurements (ratios) on the estimation of $\mathrm{r}$ and $\mathrm{R}$ values. For example the $\mathrm{R}$ values for CM6 ranged from 4.6 to 6.9 (for a mean of $\mathrm{NNN} /$ nicotine ratio that ranged from 14.2 to 14.8 ) and for $1 \mathrm{R} 5 \mathrm{~F}$ ranged from 82.3 to 141.2 (for a mean of $\mathrm{NNN}$ /nicotine ratio that ranged from 261.4 to 281.1 ). The significant differences between the minimum and the maximum reproducibility values obtained from the same dataset of NNN and nicotine yields is the consequence of uncontrolled confounding factors due to the unpaired measurements (sampling, smoking runs, extraction and analysis of analytes). Furthermore, the distribution of $\mathrm{r}$ and $\mathrm{R}$ values obtained by simulation may not reflect the reproducibility estimation obtained with paired measurements. This statistical evaluation highlighted that a robust estimate of repeatability and reproducibility for the $\mathrm{NNN} /$ nicotine ratio could not be determined with unpaired measurements, using the method defined by ISO5725-2 (19). This conclusion based on $\mathrm{NNN} /$ nicotine ratio can be extended to other analytes and other analytical methods for which each analysis is done on a different sample (unpaired measurements).

A robust estimation of the repeatability and reproducibility of ratios is crucial to legitimate the interpretation of statistical tests allowing i) products comparison or ii) determination of product compliance with a limit. Ignoring this phenomenon may lead to misleading interpretations and conclusions on the data if any maximum levels are mandated for the ratios. It is recognised that ratio precision assessment with unpaired measurements can be investigated by other approaches based on alternative statistical methods or modifications in the experimental design. For instance, the law of propagation of uncertainty based on the TAYLOR expansion allows the combination of the uncertainties of each analyte to estimate the uncertainty of a function of them (a ratio in this case), taking into account if necessary the covariance between the two variables. However, each statistical method has its own limitations. In the case of the propagation of uncertainty, the quality of the approximation for products with low nicotine levels (high relative errors) and the effect of correlation estimation between the two analytes need to be carefully evaluated. In some cases, the solution of the issue would be the development of methods allowing measurement of several analytes on one sample (paired measurements).

Any approach to estimate repeatability and reproducibility for a ratio should be discussed before starting a collaborative study and explored pragmatically, in order to recognise its theoretical and practical limitations, particularly if such a value were to be used as a basis for setting measurement tolerances.

\section{ACKNOWLEDGEMENTS}

The authors wish to thank the members of the CORESTA Special Analytes Sub Group for permission to use their collaborative study data for the analyses described in this paper.

\section{REFERENCES}

1. CORESTA Recommended Method No. 75: Determination of Tobacco Specific Nitrosamines in Mainstream Cigarette Smoke by LC-MS/MS; Cooperation Centre for Scientific Research Relative to Tobacco (2012) available at http://www.coresta.org/Recommended Methods/CRM 75.pdf (accessed August 18, 2013).

2. International Organisation for Standardisation (ISO): International Standard ISO 3308:2000. Routine Analytical Smoking Machine - Definition and Standard Conditions; ISO, Geneva, Switzerland, 2000.

3. International Organisation for Standardisation (ISO): International Standard ISO 4387:2000. Cigarettes Determination of Total and Nicotine Free Dry Particulate Matter Using a Routine Analytical Smoking Machine; ISO, Geneva, Switzerland, 2000.

4. International Organisation for Standardisation (ISO): International Standard ISO 8454:2009. Cigarettes Determination of Carbon Monoxide in the Vapour Phase of Cigarette Smoke - NDIR Method. Third edition, Amendment 1; ISO, Geneva, Switzerland, 2009.

5. International Organisation for Standardisation (ISO): International Standard ISO 10315:2000. Cigarettes - 
Determination of Nicotine in Smoke Condensates Gas-Chromatographic Method, Second edition; ISO, Geneva, Switzerland, 2000.

6. International Organisation for Standardisation (ISO): International Standard ISO 10362-1:1999. Cigarettes Determination of Water in Smoke Condensates - Part 1: Gas-Chromatographic Method, Second edition; ISO, Geneva, Switzerland, 1999.

7. European Parliament and Council: Directive 2001/37/EC of the European Parliament and of the Council of 5 June 2001 on the Approximation of the Laws, Regulations and Administrative Provisions of the Member States Concerning the Manufacture, Presentation and Sale of Tobacco Products; Off. J. Eur. Commun. L 194 (2001) 26-35.

8. Darrall, K.G.: Smoking Machine Parameters and Cigarette Smoke yields; Sci. Total Environ. 74 (1988) 263-278.

9. Hammond, D., G.T. Fong, K.M. Cummings, R.J. O'Connor, G.A. Giovino, and A. McNeill: Cigarette Yields and Human Exposure: A Comparison of Alternative Testing Regimes; Cancer Epidemiol. Biomarkers Prevent. 15 (2006) 1495-1501.

10. Pickworth, W., P. Houlgate, M. Schorp, M. Dixon, M.F. Borgerding, and G. Zaatari: A Review of Human Smoking Behaviour and Recommendations for a New ISO Standard for Machine Smoking of Cigarettes in: Report of the Ad Hoc WG9 Smoking Review Team to ISO TC126 WG9 (2005); available at: http://legacy. library.ucsf.edu/tid/mqt27a00, (accessed April 10, 2013).

11. St. Charles, F.K., A.A. Kabbani, and M.F. Borgerding: Estimating the Tar and Nicotine Exposure: Human Smoking Versus Machine Generated Smoke Yields; Regul. Toxicol. Pharmacol. 56 (2010) 100-110.

12. World Health Organization, Recommendation 1: Guiding Principles for the Development of Tobacco Product Research and Testing Capacity and Proposed Protocols for the Initation of Tobacco Product Testing; (2004) available at: http://www.who.int/tobacco/global interaction/tobreg/publications/tsr_951/en/index.html (accessed August 18, 2013).

13. Russell, M.A.: Low Tar Medium Nicotine Cigarette: A New Approach to Safer Smoking; Brit. Med. J. (1976) 1430-3.

14. World Health Organization: The Scientific Basis of Tobacco Product Regulation, Second Report of a WHO Study Group (TobReg); WHO Technical Report Series 951 (2008) ISBN 9789241209519.

15. Scherer, G.: Smoking Behaviour and Compensation: A Review of the Literature; Psychopharmacology 145 (1999) 1-20.

16. Dixon, M., N. Kochhar, K. Prasad, C.J. Shepperd, and D.M. Warburton: The Influence of Changing Nicotine to Tar Ratios on Human Puffing Behaviour and Perceived Sensory Response; Psychopharmacology 170 (2003) 434-442.

17. Purkis, S.W., V. Troude, G. Duputié, and C. Tessier: Limitations in the Characterisation of Cigarette Products Using Different Machine Smoking Regimes; Regul. Toxicol. Pharmacol. 58 (2010) 501-515.

18. Hasenfratz, M., B. Baldinger, and B. Bättig: Nicotine or Tar Titration in Cigarette Smoking Behaviour?; Psychopharmacology 112 (1993) 253-8.

19. International Organisation for Standardisation (ISO): International Standard ISO 5725-2:1994. Accuracy Ttrueness and Precision) of Measurement Methods and Results - Part 2: Basic Method for the Determination of Repeatability and Reproducibility of a Standard Measurement Method; ISO, Geneva, Switzerland, 1994.

20. International Union of Pure and Applied Chemistry (IUPAC): Harmonised Statistical Procedure; Pure Appl. Chem. 60 (1988) 855-864.

21. Efron, B. and R. Tibshirani: An Introduction to the Bootstrap; Chapman and Hall, New York, London (1993).

22. Jones, G., M. Wortberg, S.B. Kreissig, B.D. Hammock, and D.M. Rocke: Application of the Bootstrap to Calibration Experiments; Anal. Chem. 68 (1996) 763-770.

23. International Organisation for Standardisation (ISO): International Stardard 5725-6:2001. Accuracy (Trueness and Precision) of Measurement Methods and Results. Part 6. Use in Practice of Accuracy Values; ISO, Geneva, Switzerland, 2001.

24. AOAC International: Guidelines for Collaborative Study Procedures to Validate Characteristics of a Method of Analysis, Appendix D, 2002.

25. CORESTA Recommended Method No. 58: Determination of Benzo[a]pyrene in Cigarette Mainstream Smoke - Gas Chromatography-Mass Spectrometry Method; Cooperation Centre for Scientific Research Relative to Tobacco, 2004, available at: http:/www. coresta.org/Recommended_Methods/CRM_58-update (March13).pdf (accessed August 18, 2013).

26. CORESTA Recommended Method No. 63: Determination of Tobacco-Specific Nitrosamines in Cigarette Mainstream Smoke - GC-TEA Method; Cooperation Centre for Scientific Research Relative to Tobacco, 2005, available at: http://www.coresta.org/ Recommended_Methods/CRM_63.pdf (accessed August 18, 2013).

27. CORESTA Recommended Method No. 70: Determination of Selected Volatile Organic Compounds in the Mainstream Smoke of Cigarettes - Gas Chromatography-Mass Spectrometry Method; Cooperation Centre for Scientific Research Relative to Tobacco, 2010, available at: http://www.coresta.org/Re commended_Methods/CRM_70-update(March13).pdf (accessed Aügust 18, 2013).

28. International Organisation for Standardisation (ISO): International Stardard 22634:2007. Determination of Benzo[a]pyrene in Cigarette Mainstream Smoke Method using Gas Ghromatography/Mass Spectrometry; ISO, Geneva, Switzerland, 2007.

\section{Corresponding author:}

Xavier Cahours

SEITA, Imperial Tobacco Group

48 rue Danton

45404 Fleury-les-Aubrais, France

E-mail:xavier.cahours@fr.imptob.com 